\title{
HAK-HAK NORMATIF PEKERJA PADA PERUSAHAAN PAILIT
}

\author{
Oleh \\ Abuyazid Bustomi \\ Fakultas Hukum Universitas Palembang \\ Abuyazid.bustomi13.ab@gmail.com
}

\begin{abstract}
Workers have a very important role and position as actors and in national development. Therefore, there must be labor rights stipulated in the laws and regulations in Indonesia which regulate the rights and protection of workers. Protection of workers is intended to guarantee the basic rights of workers while taking into account the development of fair business actors. Normative Rights of Workers whose companies are declared bankrupt are Priority Creditors after fulfilling the rights of separatist creditors, whose payment is carried out by the curator. The Curator's Authority to the Normative Rights of Employees in Bankrupt Companies is to complete all management and repayment of Debtor's assets and debts, including the Normative Rights of workers as stipulated in Law No. 13 of 2003 and Law No. 37 of 2004 concerning Bankruptcy and Delays in the Payments of Debt Payments, that Normative Rights of Workers including Preferred Creditors or Creditors are prioritized.

Keywords: Normative Rights; Workers; Company; Bankruptcy
\end{abstract}

\begin{abstract}
ABSTRAK
Tenaga kerja memiliki peran dan kedudukan yang sangat penting sebagai pelaku dan dalam pembangunan nasional. Oleh karena itu maka harus adanya hak-hak tenaga kerja yang diatur dalam peraturan perundangan di Indonesia yang didalamnya mengatur mengenai atas hak-hak dan perlindungan terhadap pekerja. Perlindungan terhadap tenaga kerja dimaksudkan untuk menjamin hak-hak dasar pekerja dengan tetap memperhatikan perkembangan pelaku dunia usaha yang berkeadilan. Hak-Hak Normatif Para Pekerja yang perusahaannya dinyatakan Pailit tersebut menjadi Kreditur Prioritas setelah pemenuhan hak-hak kreditur separatis, yang pelaksanaan pembayarannya dilaksakan oleh curator. Kewenangan Kurator terhadap Hak Normatif Pekerja Pada Perusahaan Pailit adalah untuk menyelesaikan seluruh kepengurusan dan pemberesan harta dan hutang Debitur, termasuk Hak-Hak Normatif pekerja sebagimana yang telah diatur dalam Undang-Undang No. 13 tahun 2003 dan Undang-Undang No. 37 tahun 2004 tentang Kepailitan dan Penundaan kewajiaban Pembayaran Hutang, bahwa Hak-Hak Normatif Pekerja termasuk Kreditur Preferen atau Kreditur yang di Prioritaskan.
\end{abstract}

Kata Kunci : Hak-Hak Normatif; Pekerj; Perusahaan; Pailit 


\section{PENDAHULUAN}

\section{A. Latar Belakang}

yang tidak dapat dipisahkan dari pembangunan nasional di Republik Indonesia ini yang mana berdasarkan Undang-undang Dasar Republik Indonesia tahun 1945. Tenaga kerja memiliki peran dan kedudukan yang sangat penting sebagai pelaku dan sasaran dalam pembangunan nasional. Oleh karena itu maka harus adanya hak-hak tenaga kerja yang diatur dalam peraturan perundangan di Indonesia yang didalamnya mengatur mengenai atas hak-hak serta perlindungan terhadap karyawan/pekerja. Perlindungan terhadap tenaga kerja dimaksudkan untuk menjamin hak-hak dasar pekerja dengan tetap memperhatikan perkembangan kemajuan dunia usaha nasional maupun internasional.

Kepailitan menurut Undang-undang Republik Indonesia No. 37 Tahun 2004 tentang Kepailitan dan Penundaan Kewajiban Pembayaran Utang yang terdapat dalam Pasal 1 angka 1 dijelaskan bahwa sita umum atas kekayaan debitor pailit yang pengurusan dan pemberesannya dilakukan oleh kurator dibawah pengawasan hakim pengawas. Undang-undang Republik Indonesia No. 37 Tahun 2004 tentang Kepailitan dan Penundaan Kewajiban pembayaran utang dalam Pasal 39 disebutkan bahwa (1) "Pekerja yang bekerja pada debitor dapat memutuskan hubungan kerja, dan sebaliknya kurator dapat memberhentikannya dengan mengindahkan jangka waktu menurut persetujuan atau ketentuan perundang-undangan yang berlaku, dengan pengertian bahwa hubungan kerja tersebut dapat diputuskan dengan pemberitahuan paling singkat 45 (empat puluh lima) hari sebelumnya; dan (2) sejak tanggal putusan pernyataan pailit diucapkan, upah yang sebelum maupun sesudah putusan pernyataan pailit diucapkan merupakan utang harta pailit".

Peraturan ini diharapkan mampu memberikan jawaban mengenai hak-hak pekerja pada saat perusahaan pailit. Meskipun demikian adanya Undang-undang Kepailitan dan Penundaan Kewajiban Pembayaran Utang tersebut masih belum bisa menjembatani kepentingan ketiga pihak yang berkepentingan, diantaranya pengusaha, pekerja, dan kerditur.

Terkait dengan kepentingan pekerja/buruh terhadap suatu perusahaan yang dinyatakan pailit adalah berkaitan dengan pembayaran upah dan pesangon. Sedangkan, tagihan pembayaran upah buruh dikategorikan sebagai hak istimewa. Ketentuan tersebut diatur dalam Pasal 95 ayat (4) UU Nomor 13 Tahun 2003 tentang Ketenagakerjaan. Pasal 95 ayat (4) UU Nomor 13 Tahun 2003 : "Dalam perusahaan dinyatakan pailit atau dilikuidasi berdasarkan peraturan perundangundangan yang berlaku, maka upah dan hakhak lainnya dari pekerja/buruh merupakan utang yang didahulukan pembayarannya. ${ }^{1}$ Sehingga, ada jaminan bahwa hak-hak karyawan atas upah/pesangon bisa terpenuhi. ${ }^{2}$

Dengan adanya kreditur-kreditur yang memegang jaminan, sering kali para buruh khawatir tidak terbayar upah dan pesangonnya karena harta perusahaan sebagai debitur habis atau telah berkurang banyak untuk membayar kreditur pemegang jaminan.Sehingga mengakibatkan hak-hak buruh pada perusahaan pailit menjadi kabur. Hal tersebut mendorong penulis untuk meneliti dan menelaah lebih lanjut mengenai hal-hal yang berkaitan dengan hak-hak para pekerja saat perusahaan pailit berdasarkan Undang-undang Republik Indonesia No. 37 Tahun 2004, Undang-undang No. 2 tahun 2004 dan Undang-Undang Republik Indonesia No. 13 Tahun 2003 tentang Ketenagakerjaan.

Berdasarkan uraian diatas, maka penulis tertarik untuk menuangkan tulisan dengan judul "PENERAPAN HAK-HAK NORMATIF BAGI PEKERJA PADA PERUSAHAAN PAILIT.

\footnotetext{
${ }^{1}$. S. Sastrawidjaja, Hukum Kepailitan dan Penundaan Kewajiban Pembayaran Utang, Jakarta, 2010, pasal 95 ayat (4).

2. Jono, Hukum Kepailitan, Sinar Grafika, Jakarta, 2013, hlm 107
} 


\section{B. Permasalahan}

Berdasarkan pada uraian-uraian tersebut diatas, maka penulis dapat merumuskan permasalahannya sebagai berikut

1. Bagaimana Penerapan Hak-Hak Normatif bagi Pekerja Pada Perusahaan Pailit?

2. Bagaimanakah kewenangan dan tanggung jawab kurator terhadap hak normatif pekerja pada perusahaan yang dinyatakan pailit ?

\section{Ruang Lingkup dan Tujuan}

Ruang lingkup penelitian dititik beratkan pada penerapan hak-hak normatif pekerja pada perusahaan pailit yang merupakan kewenangan dan tanggung jawab curator pada perusahaan yang dinyatakan pailit oleh pengadilan. Adapun tujuan penelitian ini antara lain :

1. Untuk mengetahui bagaimana Penerapan Hak-hak normatif bagi Pekerja Pada Perusahaan yang Pailit.

2. Untuk mengetahui bagaimana kewenagan dan tanggung jawab curator terhadap Hak-Hak Normatif pekerja pada perusahaan yang terkena Pailit.

\section{Metodologi}

Selaras dengan hak-hak normatif pekerja pada perusahaan pailit yang menjadi kewenangan dan tanggung jawab curator menurut ketentuan Undang-Undang No. 37 tahun 2004 dan Undang-Undang No. 13 tahun 2003, dengan demikian penelitian tergolong jenis penelitian Hukum Normatif yaitu suatu penelitian yang bertujuan untuk dapat menjelaskan dan menguji suatu teori yang telah ada sebelumnya. Penelitian Hukum Normatif adalah pengkajian terhadap bahanbahan hukum baik bahan Hukum Primer maupun bahan Hukum Sekunder. Dalam penelitian ini bahan hukum yang dipergunakan mencakup : ${ }^{3}$

3. Soerjono Soekanto dan Sri Mamudji, Penelitian Hukum Normatif, PT. Raja Grafindo Persada, Jakarta, 2001, hlm 13.
1. Bahan Hukum Primer

a. Kitab Undang-undang Hukum Perdata.

b. Undang-Undang No. 13 Tahun 2003 tentang Ketenagakerjaan.

c. Undang-Undang No. 37 Tahun 2004 tentang tentang Kepailitan dan Penundaan Kewajiban Pembayaran Utang.

.Bahan Hukum Sekunder

a. Kepustakaan atau buku-buku yang merupakan hasil karya para pakar (tokoh) dan sarjana yang menguraikan tentang hukum perlindungan konsumen.

b. Makalah-makalah tentang Hukum Ketenagakerjaan dan juga Hukum Kepailitan.

\section{TINJAUAN PUSTAKA}

\section{A. Pengertian dan Pengaturan Kepailitan}

Pailit merupakan"Debitur yang mempunyai dua atau lebih kreditur dan tidak membayar lunas sedikitnya satu utang yang telah jatuh waktu dan dapat ditagih, dinyatakan pailit dengan putusan pengadilan, baik atas permohonannya sendiri maupun atas permohonan satu atau lebih krediturnya". Syarat-syarat permohonan pailit sebagaimana ditentukan dalam pasal 2 ayat(1) UU kepailitan, Syarat adanya dua kreditur atau lebih (concursus creditorum) adalah kreditur konkuren, kreditur preferen dan kreditur separatis.

Dengan adanya pranata hukum kepailitan, diharapkan pelunasan utang-utang debitur kepada keditur-keditur dapat dilakukan secara seimbang dan adil. Setiap kreditur preferen $^{4}$ (yang diistimewakan ), yaitu kreditur yang oleh undang-undang, semata-mata karena sifat piuntangnya, mendapatkan perlunasan terlebih dahulu. Kreditur preferens merupakan kreditur yang mempunyai hak

\footnotetext{
${ }^{4}$. Kartini Muljadi, Kreditor Preferens dan Kreditor Separatis Dalam Kepailitan, "Prosiding rangkaian lokakarya terbatas masalah-masalah kepailitan dan wawasan hukum bisnis lainnya, Pusat Pengkajian Hukum, Jakarta, 2004. hlm 164-165.
} 
istimewa, yaitu suatu hak yang oleh undangundang diberikan kepada seorang piutang sehingga tingkatnya lebih tinggi daripada orang berpiutang lainnya, semata-mata berdasarkan sifat piutangnya (Pasal 1134 KUH Perdata). ${ }^{5}$

Terhadap perusahan yang menjalankan setiap jenis usaha yang bersifat tetap dan bekerja terus menerus, didirikan dan berkedudukan diwilkayah negara Indonesia untuk memperoleh keuntungan dan atau laba, 6 dimana perusahaan tersebut mengalami masalah keuangan dan tanggung jawab kepada para kreditur telah jatuh tempo, yang akhirnya menyebabkan perusahaan tersebut dinyatakan pailit. Untuk mengetahui hutang-hutang mana yang diistimewakan dapat dilihat dalam pasal 1139 dan pasal 1149 Kuh Perdata. Menurut pasal 1139 hutang-hutang yang diistimewakan terhadap benda-benda tertentu, antara lain:

1. Biaya perkara yang semata-mata yang disebabkan oleh suatu penghukuman untuk melelang suatu benda bergeak maupun tidak bergerak. Biaya ini dibayar dari pendapatan penjualan benda tersebut terlebih dahulu dari semua piutang lainnya yang diistimewakan, bahkan lebih dahulu pula daipada gadai dan hipotek;

2. Uang sewa dari benda tidak bergerak, biaya perbaikan yang menjadi kewajiban si penyewa, beserta segala apa yang mengenai kewajiban memenuhi persetujuan sewa.

3. Harta pembelian benda-benda bergerak yang belum dibayar.

4. Biaya yang telah dikeluakan untuk menyelamatkan suatu barang.

5. Biaya untuk melakukan pekerjaan pada suatu barang/kepada seorang tukang.

6. Apa yang telah diserahkan oleh seorang pengusaha rumah penginapan sebagai demikian kepada seorang tamu.

7. Upah-upah pengakutan dan biaya-biaya tambahan.

\footnotetext{
${ }^{5}$. Jono, Op cit, hlm 5

6. C.S.T Kansil \& Charistine Kansil, I Hukum

Perusahaan Indonesia (Aspek Hukum Dalam ekonomi, PT. Praddnya Paramita, Jakarta, 2001, HIm. 4.
}

8. Apa yang harus dibayar kepada tukang batu, tukang kayu, dan lain-lain tukang untuk pembangunan, penambahan dan pebaikan benda-benda tidk bergerak, asal saja piutangnya tidak lebih tua dari tiga tahun dan hak milik atas persil yang bersangkutan masih tetap pada si berutang.

9. Pergantian serta pembayaran yang harus dipikul oleh pengawai yang memangku suatu jabatan umum, karena segala kelalaian, kesalahan pelanggaan, dan kejahatan yang dilakukan dalam jabatannya. $^{7}$

Adapun pasal 1149 Kuh Perdata menentukan bawha piutang-piutang yang diistimewakan atas semua benda bergerak dan tidak begerak pada umumnya adalah yang disebutkan dibawah ini, piutang-piutang mana dilunasi dan pendapatan penjualan bendabenda itu menurut urutan sebagai berikut :

1. Biaya- biaya perkara, yang semata-mata disebabkan oleh pelelangan dan penyelesaian suatu warisan; biaya-biaya ini didahulukan daripada gadai dan hipotek,

2. Biaya-biaya penguburan, dengan tidak mengurangi kekuasaan hakim untuk menguranginya, jika biaya itu terlampau tinggi.

3. Semua biaya perawatan dan pengobatan dari sakit yang penghabisan.

4. Upah para buruh selama tahun yang lalu dan upah yang sudah dibayar dalam tahun yang sedang berjalan, beserta jumlah uang kenaikan upah menurut pasal 1602q.

5. Piutang karena penyeahan bahan-bahan makanan yang dilakukan kepada si berutang berseta keluaganya, selama waktu enam bulan yang terakhir

6. Piutang-piutang para pengusaha sekolah berasrama untuk tahun yang penghabisan.

7. Piutang anak-anak yang belum dewasa dan orang-orang yang terampil terhadap sekalian wali dan pengampu mereka.

\section{B. Pengertian Hukum Ketenagakerjaan}

\footnotetext{
${ }^{7}$. Ibid, hlm 6
} 
Hukum ketenagakerjaan dahulu disebut hukum peburuhan yang merupakan suatu hubungan hokum yang berkaitan dengan hubungan kerja, dimana pekerjaan itu dilakukan dibawah pimpinan dan dengan keadaan penghidupan yang langsung bersangkutan paut dengan hubungan kerja itu. Imam Soepomo memberikan batasan pengertian hukum perburuhan adalah suatu himpunan peraturan, bak tertulis maupun tidak tertulis yang berkenaan dengan kejadian dimana seorang bekeja pada orang lain dengan menerima upah. ${ }^{8}$ Untuk dapat melaksankan tujuan dibidang ketenagakerjaan berdasarkan ketentuan pasal 8 UU No 13 Tahun 2003, ditetapkanlah perencanaan tenaga kerja dan informasi ketenagakerjaan yaitu :

1. Perencanaan tenaga kerja disusun atas dasar inovasi ketenagakerjaan antara lain meliputi :

a. penduduk dan tenaga kerja

b. kesenpatan kerja

c. pelatihan kerja termasuk kompetensi keja

d. produktivtas kerja

e. hubungan industrial

f. kondisi lingkungan kerja

g. pengupahan dan kesejahteraan tenaga kerja

h. jaminan social tenaga kerja.

2. Informasi ketenagakejaan sebagaimana dimaksud dalam ayat (1), diperoleh dari semua pihak yang terkait, baik instasi pemerintah maupun swasta.

3. Ketentuan tata cara memperoleh informasi ketenagakejaan dan penyusunan serta pelaksanaan perencanaan tenga kerja sebagaimana dimaksud dalam ayat (1) diatur dengan peraturan pemerintah.

\section{Hubungan Kerja}

Dalam melaksanakan pembangunan nasional, peran serta buruh semakin meningkat dan seiring dengan itu perlindungan buruh harus semakuin

8. Imam Soepomo, Pengantar Hukum

Perburuhan, Djambatan, Jakarta, 2003, hlm 13. ditingkatkan baik upah, kesejahteraan, dan harkatnya sebagai manusia (to make mare human $)^{9}$. Berdasarkan ketentuan pasal 1 angka 14 Undang-Undang No. 13 Tahun 2003. Hubungan kerja adalah hubungan antara pengusaha dengan pekerja/buruh berdasarkan perjanjian kerja yang mempunyai unsur pekerjaan, upah dan peintah.

Unsur-Unsur perjanjian kerja yang menjadi dasar hubungan kerja sesuai dengan ketentuan pasal 1 angka 4 Undang-Undang No 13 Tahun 2003 adalah:

1. Adanya pekerjaan( arbeid)

2. Dibawah perintah/ gezag ver houding ( maksudnya buruh melakukan pekerjaan atas perintah majikan, sehingga bersifat subordinasi)

3. Adanya upah tertentu/loan

4. Dalam waktu (tijd) yang ditentukan ( dapat tanpa baas waktu/pension atau berdasarkan waktu tertentu ). ${ }^{10}$

Hubungan kerja antara pekerja /buruh dengan pengusaha terdiri atas hubungan kerja tetap dan hubungan kerja tidak tetap. Dalam hubungan kerja tetap, perjanjian kerja antara pekerja / buruh dengan pengusaha berdasarkan perjanjian kerja untuk waktu tidak tertentu ( PKWTT), sedangkan dalam hubungan kerja tidak tetap antara pekerja/buruh dengan pengusaha didasarkan pada perjanjian kerja waktu tertentu( PKWT).

\section{Pemutusan Hubungan Keja ( PHK )}

Pemutusan hubungan kerja badan usaha yang bebadan hukum atau tidak, milik orang orang perseorang, milik persekutuan atau badan hukum, baik milik swasta maupun milik negara, maupun usaha-usaha sosial dan usaha-usaha lainnya yang mempunyai pengurus dan mempekerjakan orang lain dengan membayar upah atau imbalan dalam bentuk lain.

\footnotetext{
9. Adrian Sutedi, Hukum Perburuhan, Sinar Grafika, Jakarta, 2009 , hlm 37

10. Asri Wijayanti, Hukum Ketenagakerjaan Pasca

Reformasi, Sinar Grafika, Jakarta, hlm 36
} 
PHK berarti suatu keadaan diamana si buruh berenti bekerja dari majikan. Hakikatnya PHK bagi buruh merupakan awal dari penderitaan, maksudnya bagi buruh permulaan dari segala pengakhiran, permulaan dari membiayai keperluan hidup sehari-hari baginya dan keluarganya. Pengusaha, serikat pekerja, dan pemerintah harus mengusahakan agar jangan terjadinya pemutusan hubungan kerja (pasal 151 ayat(1) Undang-Undang No 13 Tahun 2003 ) selanjutnya, berdasarkan ketentuan pasal 151 ayat(2) dan (3) UndangUndang No 13 Tahun 2003 yaitu :

1. Dalam hal segala upaya telah dilakukan, tetapi pemutusan hubungan kerja tidak dapat dihindari, maka maksud pemutusan hubungan kerja wajib dirundingkan oleh pengusaha dan serikat buruh atau dengan pekerja/buruh apabila pekerja/buruh yang bersangkutan tidak menjadi anggota serikat/pekerja/ serikat buruh.

2. Dalam hal perundingan sebagaimana dimaksud dalam ayat (2) benar-benar tidak menghasilkan persetujuan, pengusaha hanya dapat memutuskan hubungan kerja dengan pekerja/ buruh setelah memperoleh penetapan dari lembaga penyelelesaian perselisihan hubungan industrial. ${ }^{11}$

Dalam Literatur hukum ketenagakerjaan, dikenal adanya beberapa jenis pengakhiran hubungan kerja (PHK) yaitu

1. PHK oleh majikan majikan/ pengusaha, yaitu oleh pihak pengusaha terjadinya karena keinginan dari pihak pengusaha dengan alasan, persyaratan, dan prosedur tertentu.

2. PHK oleh pekerja/buruh yaitu PHK oleh pihak pekerja terjadi karena keinginan dari pihak pekerja dengan alasan dan prosedur tertentu.

3. PHK demi hukum yaitu PHK yang terjadi perlu adanya suatu tindakan, terjadi dengan sendirinya misalnya

\footnotetext{
${ }^{11}$. Asri wijayanti, Op cit, hlm 159
}

karena berakhirnya waktu atau karena meninggalnya pekerja.

4. PHK oleh pengadilan (PPHI), yaitu PHK oleh putusan pengadilan terjadi karena alasan-alasan tertentu yang mendesak dan penting, misalnya tejadinya peralihan kepemilikan, peralihan aset atau pailiit.

Pengaturan penyelesaian PHK dalam hukum ketenagakerjaan kita pada masa yang akan datang sesuai dengan Undang-Undang Penyelesaian Perselisihan Industrial dilakukan oleh Pengadilan Perselisihan Industrial yang merupakan oleh Pengadilan Perselisihan Industrial yang merupakan peradilan ad hoc di Pengadilan Negeri. ${ }^{12}$

\section{Hak-Hak Tenaga Kerja yang di PHK}

Bilamana terjadi pemutusan hubungan kerja, pengusaha mempunyai kewajiban untuk membayar uang pesangon dan atau uang penghargaan masa kerja dan uang pergantian hak yang seharunya diterima sebagaiman dimaksud dalam pasal 156 UU N0.13 thn 2013 yaitu :.

\section{Uang Pesangon}

Uang pesangon merupakann pembayaran dalam bentuk uang dari pengusaha kepada buruh/pekerja sebagai akibat adanya phk yang jumlahnya disesuaikan dengan masa kerja buruh/pekerja yang bersangkutan. Perhitungan uang pesangon diatur dalam Undang-Undang No 13 Tahun 2003 Tentang Ketenagakerjaan sebagai berikut ${ }^{13}$ :

a. Masa Kerja kurang dari 1 (satu) tahun, 1 (satu) bulan upah;

a. Masa Kerja 1 tahun atau lebih tetapi kurang dari 2 (dua) tahun, 2 (dua) bulan upah;

b. Masa Kerja 2 tahun atau lebih tetapi kurang dari 3 (tiga) tahun, 3 (tiga) bulan upah;

c. Masa Kerja 3 tahun atau lebih tetapi kurang dari 4 tahun, 4 (empat) bulan upah;

\footnotetext{
${ }^{12}$. Lalu Husni, Pengatar Hukum Ketenagakerjaan Indonesia, Edisi Revisi, PT . Raja Grafindo Persada, Jakarta, 2009, hlm 207

13. Ibid, HIm 208
} 
d. Masa Kerja 4 tahun atau lebih tetapi kurang dari 5 tahun, 5 (lima) bulan upah;

e. Masa Kerja 5 tahun atau lebih, tetapi kurang dari 6 tahun, 6 (enam) bulan upah;

f. Masa Kerja 6 tahun atau lebih tetapi kurang dari 7 (tujuh) tahun, 7 (tujuh) bulan upah.

g. Masa Kerja 7 tahun atau lebih tetapi kurang dari 8 tahun, 8 (delapan) bulan upah;

h. Masa Kerja 8 (delapan) tahun atau lebih, 9 (sembilan) bulan upah pasal 156 ayat 2.

\section{Uang Penghargaan Masa Kerja}

Perhitungan uang penghargaan masa kerja sebagaimana dimaksud dalam ayat (1) ditetapkan sebagai berikut :

a. Masa Kerja 3 tahun atau lebih tetapi kurang dari 6 (enam) tahun, 2 (dua) bulan upah;

b. Masa Kerja 6 (enam) tahun atau lebih tetapi kurang dari 9 tahun, 3 (tiga) bulan upah;

c. Masa Kerja 9 tahun atau lebih tetapi kurang dari 12 tahun, 4 (empat) bulan upah;

d. Masa Kerja 12 tahun atau lebih tetapi kurang dari 15 tahun, 5 (lima) bulan upah;

e. Masa Kerja 15 tahun atau lebih tetapi kurang dari 18 tahun, 6 (enam) bulan upah;

f. Masa Kerja 18 tahun atau lebih tetapi kurang dari 21 tahun, 7 (tujuh) bulan upah;

g. Masa Kerja 21 tahun atau lebih tetapi kurang dari 24 tahun, 8 (delapan) bulan upah;

h. Masa Kerja 24 tahun atau lebih, 10 (sepuluh ) bulan upah pasal 156 ayat 3 .

\section{Uang Pengantian Hak}

Uang penggantian hak yang seharusnya diterima sebagaimana dimaksud dalam ayat (1) meliputi :

a. Cuti tahunan yang belum diambil dan belum gugur;

b. Biaya atau ongkos pulang untuk pekerja/buruh dan keluarganya ketempat dimana pekerja/buruh diterima bekerja;

c. Penggantian perumahan serta pengobatan dan perawatan ditetapkan $15 \%$ (lima belas perseratus) dari uang pesangon dan/atau uang penghargaan masa kerja bagi yang memenuhi syarat;

d. Hal-hal lain yang ditetapkan dalam perjanjian kerja, peraturan perusahaan atau perjanjian kerja bersama.(pasal 156 ayat 4 .

Komponen upah terdiri atas tiga macam, yakni upah pokok (UP), tunjangan tetap (TT) dan tunjangan tidak tetap (TTT). Komponen upah yang dijadikan dasar perhitungan uang pesangon, uang penghargaan masa kerja, dan uang pergantian hak yang seharusnya diterima yang tertunda adalah Upah pokok. Dan Tunjangan yang bersifat tetap, yang diberikan kepada pekerja dan keluarganya.

\section{PEMBAHASAN}

\section{A. Penerapan Hak-Hak Normatif Bagi} Pekerja Pada Perusahaan yang Pailit

Tenaga kerja selalu menjadi pihak yang lemah apabila dihadapkan pada pemberi kerja yang merupakan pihak yang memiliki kekuatan. Sebagai pihak yang selalu dianggap lemah, tidak jarang para tenaga kerja selalu mengalami ketidakadilan apabila berhadapan dengan kepentingan perusahaan.

Akibat dari PHK dapat ditinjau dari pihak majikan dan dari pihak buruh. Dari pihak majikan/pengusaha, PHK dapat menyebabkan terganggunya proses produksi yang akibatnya perusahaan merugi, pengeluaran biaya tambahan akibat harus memberi pesangon dan perusahaan dapat kehilangan tenaga yang terampil Jika dilihat dari sudut pandang tenaga kerja/buruh, PHK dapat mengakibatkan kehilangan nafkah dan kehilangan status. Kehilangan nafkah dapat dikompensasikan dengan pemberian uang pesangon, uang jasa/penghargaan masa kerja, dan anti kerugian.

Dalam hal pemutusan hubungan kerja dilakukan kurator, pemutusan kerja harus sesuai dengan pasal 165 UUTK, antara lain : 
"pengusaha dapat melakukan pemutusan hubungan kerja terhadap pekerja buruh karena perusahaan pailit, dengan ketentuan pekerja/buruh berhak atas uang pesangon sebesar1 1 (satu) kali ketentuan pasal 156 ayat(2), uang penghargaan masa kerja sebesar 1(satu) kali ketentuan pasal 156 ayat(3) dan uang pergantian hak sesuai ketentuan pasal 156 ayat(4)".

Apabila perselisihan hubungan industrial tersebut, telah dilakukan upaya musyawarah lewat bipartite dan tripartite sebagai diatur dalam Undang-Undang Lembaga Penyelesaian Perselisihan Hubungan Ibndustrial, namun tidak tercapai kesepakatan maka Para Penggugat akan mencari keadilan melalui Pengadilan Perselisihan Hubungan Industrial;

Oleh karenanya gugatan yang diajukan harus berdasarkan pada bukti-bukti otentik serta sesuai dengan ketentuan perundangundangan yang berlaku, selanjutnya Penggugat mohon agar Pengadilan Perselisihan Hubungan Industrial dapat menyatakan putusan ini dapat dilaksanakan terlebih dahulu walaupun diadakan upaya hukum (uit voerbar bij vooraad) kasasi oleh karena timbulnya perkara ini akibat kesalahan Tergugat.

\section{B. Kewenangan dan Tanggung Jawab Kurator Terhadap Hak Normatif Pekerja Pada Perusahaan Pailit}

Sebagai akibat Perusahaan pailit besar kemungkinan putusan pailit tersebut memberikan dua kemungkinan alternatif bagi Perusahaan. Pertama, meski perusahaan telah dinyatakan pailit, kurator Perusahaan pailit dapat tetap menjalankan kegiatan usahanya dengan konsekwensi tetap membayar biaya usaha seperti biaya listrik, telepon, biaya gaji, pajak, dan biaya lainnya. Kedua, kurator perusahaan pailit berhak melakukan pemutusan hubungan kerja dengan dasar pasal 165 Undang-Undang No. 13 Tahun 2003.

Pailit merupakan suatu keadaan dimana debitur tidak mampu untuk melakukan pembayaran-pembayaran terhadap utangutang dari para krediturnya. Keadaan tidak mampu membayar lazimnya disebabkan karena kesulitan kondisi Keuangan (financial distress) dari usaha debitur yang telah mengalami kemunduran. ${ }^{14}$ Sedangkan kepailitan merupakan putusan pengadilan yang mengakibatkan sita umum atas seluruh kekayaan debitur pailit, baik yang telah ada mau punya tidak akan ada dikemudian hari. Pengurusan dan pemberesan kepailitan dilakukan oleh kurator dibawah pengawasan hakim pengawas dengan tujuan utama menggunakan hasil penjualan harta kekayaan

Berdasarkan Undang-Undang Republik Indonesia Nomor 37 Tahun 2004 tentang Kepailitan dan Penundaan Kewajiban Pembayaran Utang Pasal 22, harta debitur pailit yang sudah ada pada saat Debitur dinyatakan pailit oleh Pengadilan Niaga maupun yang akan diperoleh selama kepailitan berlangsung digunakan untuk membayar semua krediturnya secara adil dan merata yang dilakukan seorang Kurator di bawah pengawasan Hakim Pengawas.

Untuk lebih memahami wewenang dan tanggung jawab kurator dalam rangka pengurusan harta boedel pailit sesuai UndangUndang Republik Indonesia Nomor 37 Tahun 2004 tentang Kepailitan dan Penundaan Kewajiban Pembayaran Utang ${ }^{15}$ yaitu :

1. Pada pengertian secara umum tugas dari Kurator dalam Hal pernyataan Pailit Debitor adalah mengurus dan membereskan harta Debitor Pailit dibawah pengawasan Hakim Pengawas sesuai dengan Pasal 1 angka 5 dan Pasal 69 ayat 1 UU Kepailitan dan PKPU.

2. Dalam hal melaksanakan tugasnya, Kurator tidak diharuskan memperoleh persetujuan dari atau menyampaikan pemberitahuan terlebih dahulu kepada Debitor atau salah satu Debitor, meskipun dalam keadaan diluar kepailitan persetujuan atau pemberitahuan demikian

\footnotetext{
14. Munir Fuady, Hukum Pailit Dalam Teori dan

Praktek, PT.Citra Aditya Bakti,Bandung, 1998, Hlm. 8

15. H. Tafrizal Hasan Gaweng, Panduan Singkat
}

Praktek Kurator, THG, Yustisian, 2005, Hlm. 9.10. 
dipersyaratkan (Pasal 69 ayat 2 huruf a).

3. Pada saat melaksanakan tugasnya kurator dapat melakukan pinjaman dari pihak ketiga, hanya dalam meningkatkan nilai harta pailit dengan persetujuan lebih dahulu Hakim Pengawas (Pasal 69 ayat 3 dan 4).

4. Dalam hal melaksanakan tugas pengurusan dan/atau pemberesan atas harta pailit diucapkan, tetap berwenang meskipun terhadap putusan tersebut diajukan kasasi dan atau peninjauan kembali (Pasal 16 ayat 1 ).

5. Jika putusan pernyataan pailit dibatalkan sebagai akibat adanya kasasi atau peninjauan kembali, segala perbuatan yang dilakukan oleh kurator sebelum atau pada tanggal Kurator menerima pemberitahuan tentang putusan pembatalan sebagaimana dimaksud Pasal 17 tetap sah dan mengikat Debitur (Uit voor baar bij voor raad Pasal 16 ayat 2).

6. Dalam melaksanakan tugasnya Kurator bertanggung jawab terhadap kesalahan atau kelalaiannya dalam melaksanakan tugas pengurusan dan/atau pemberesan yang menyebabkan kerugian terhadap harta pailit (Pasal 72).

Sejak mulai pengangkatannya, Kurator harus melaksanakan semua upaya untuk mengamankan harta pailit dan menyimpan semua surat, dokumen, uang perhiasan, efek, dan surat berharga lainnnya dengan memberikan tanda terima (Pasal 98). Secara rinci tugas Kurator yaitu :

1. Membuat daftar harta pailit debitor (Pasal 100).

2. Membuat daftar piutang kreditor (Pasal 113, Pasal 114, Pasal 115, Pasal 116, Pasal 117, Pasal 118).

3. Kurator wajib memasukan piutang yang disetujuinya ke dalam suatu daftar piutang yang sementara diakui, sedangkan piutang yang dibantah termasuk alasannya dimasukkan kedalam daftar tersendiri (Pasal 117).

4. Dalam daftar sebagaimana dimaksud Pasal 117, dibubuhkan pula cataan terhadap setiap piutang apakah menurut pendapat Kurator piutang yang bersangkutan diistimewakan atau dijamin dengan gadai, jaminan fidusia, hak tanggungan, hipotek, hak agunan atas kebendaanlainnya, atau hak untuk menahan benda bagi tagihan yang bersangkutan dapat dilaksanakan (Pasal 118 ayat 1 ).

5. Apabila Kurator hanya membantah adanya hak untuk didahulukan atau adanya hak untuk menahan benda, piutang yang bersangkutan harus dimasukkan dengan daftar piutang yang bersangkutan yang untuk sementara diakui berikut catatan Kurator tentang bantahan serta alasannya (Pasal 118 ayat 2).

Dalam hal ini, Kurator memiliki tugas dan wewenang yang sangat luas sekali tentang pembagian harta boedel pailit, tetapi sangat sedikit sekali yang menyinggung masalah perlindungan hak buruh atau upah walaupun memang diatur dalam Pasal 39 ayat (1) dan (2) yang menyatakan (1) pekerja yang bekerja pada Debitor dapat memutuskan hubungan kerja, dan sebaliknya Kurator dapat memberhentikannya dengan mengindahkan jangka waktu menurut persetujuan atau ketentuan, (2) menyatakan sejak tanggal putusan pernyataan pailit diucapkan merupakan utang harta pailit. Tetapi dalam UUK ini tidak dibahas lebih rinci sampai sejauh mana pembayaran dan perlindungan pembayaran upah (hak normatif pekerja) apabila harta boedel tidak cukup untuk melunasiya.

Mengenai tanggung jawab Kurator (Pasal 78 ayat (2) UUK menyatakan bahwa Kurator bertanggung jawab terhadap Debitot Pailit dan Kreditor. Kemudian Kurator juga bertanggung jawab terhadap kesalahan atau kelalaiannya dalam melaksanakan tugas pengurusan dan/atau pemberesan yang menyebabkan kerugian terhadap harta pailit (Pasal 72 UUK). Sedangkan menurut UndangUndang Republik Indonesia Nomor 13 Tahun 2003 tentang Ketenagakerjaan Pasal 95 ayat (4) dinyatakan " Dalam hal perusahaan dinyatakan pailit atau dilikuidasi berdasarkan 
peraturan Perundang-undangan yang berlak, maka upah dan hak-hak lainnya dari pekerja/buruh merupakan utang yang didahulukan pembayarannya".

Dalam ketentuan Pasal 165 UU No. 13

Tahun 2003 tentang Ketenagakerjaan mengatur bahwa Pengusaha dapat melakukan pemutusan hubungan kerja terhadap pekerja/buruh karena perusahaan pailit, dengan ketentuan pekerja/buruh berhak atas uang pesangon sebesar 1 kali ketentuan Pasal 156 ayat 3 , dan uang penggantian hak sesuai ketentuan Pasal 156 ayat 4. Ketentuan didalam pasal tersebut juga dinyatakan dalam Pasal 39 ayat 1 Undang-undang No. 37 Tahun 2004 tentang Kepailitan dan Penundaan Kewajiban Pembayaran Utang:Pekerja yang bekerja pada Debitor dapat memutuskan hubungan kerja, dan sebaliknya Kurator dapat memberhentikannya dengan mengindahkan jangka waktu menurut persetujuan atau ketentuan perundang-undangan yang berlaku, dengan pengertian bahwa hubungan kerja tersebut dapat diputuskan dengan pemberitahuan paling singkat 45 hari sebelumnya.

Ketika terjadi Pailit pembayaran upah pekerja/buruh dilakukan oleh Kurator yang dalam hal ini menggantikan posisi Perusahaan. Sehingga hak buruh dalam hal ini upah dan tunjangan lainnya menurut Undang-Undang Ketenagakerjaan akanberubah menjadi utangyang didahulukan pembayarannya. Dan penjelasannya menyebutkan yang dimaksud didahulukan pembayarannya adalah upah pekerja/buruh harus dibayar lebih dahulu daripada utang-utang lainnya. Dalam pasal 39 ayat (2) Undang -Undang No. 37 Tahun 2004 tentang Kepailitan dan Penundaan Kewajiban Pembayaran Utang telah ditentukan bahwa upah buruh untuk waktu sebelum dan sesudah pailit termasuk utang harta pailit artinya upah buruh harus dibayar lebih dahulu daripada utang-utang lainnya.

Melihat kenyataan ini, antara perlindungan hak pekerja dalam UUK dan UU Ketenagakerjaan terdapat perbedaan yang signifikan, di dalam UUK upah buruh untuk waktu sebelum dan sesudah pailit termasuk utang harta pailit artinya upah buruh harus dibayar lebih dahulu daripada utang-utang lainnya tetapi tidak jelas diatur utang yang lainnya ini utang yang mana dan bagaimana proses penyelesaiannya. Sementara dalam UU Ketenagakerjaan juga menyakan hal yang sama yaitu Pasal 95 ayat (4), secara jelas dan gamblang menekankan bahwa upah dan hakhak lainnya dari pekerja/buruh merupakan utang yang didahulukan pembayarannya unutk melindungi dan menjamin keberlangsungan hidup dan keluarganya.

Dalam hal ini upah buruh menurut UU Ketenagakerjaan menjadi prioritas pertama yang harus dibayarkan tanpa syarat apapun karena hal ini langsung berhubungan dengan nasib dan hidup dari pekerja/buruh dan keluarga, sedangkan menurut UUK hal ini tidak berlaku mutlak dikarenakan adanya penggolongan kreditor berdasarkan Pasal 1131 sampai dengan Pasal 1138 Kitab UndangUndang Hukum Perdata jo. Undang-Undang No. 20 Tahun 2007 tentang Perubahan Ketiga atas Undang-Undang No.6 Tahun 1983 tentang Ketentuan Umum dan Tata Cara Perpajakan (UU KUP); dan Undang-Undang No. 37 Tahun 2004 tentang Kepailitan dan PKPU, yang membagi golongan kreditur menjadi :

1. Kreditor yang kedudukannya di atas kreditur saham jaminan kebendaan (contohnya utang pajak) dimana dasar hukum mengenai kreditur ini terdapat dalam Pasal 21 UU KUP jo Pasal 1137 KUH Perdata;

2. Kreditur pemegang jaminan kebendaan yang dianut sebagai Kreditur Separatis (dasar hukumnya adalah Pasal 1134 ayat 2 KUHPer). Hingga hari ini jaminan kebendaan yang diatur di Indonesia meliputi :
a. Gadai;
b. Fidusia;
c. Hak Tanggungan;
d. Hipotik Kapal.

3. Utang harta pailit, yang termasuk utang harta pailit antaralain sebagai berikut :

a. Biaya kepailitan dan fee Kurator; 
b. Upah buruh, baik untuk waktu sebelum Debitur pailit maupun sesudah Debitur pailit (Pasal 39 (2) UUK, dan

c. Sewa gedung sesudah Debitur pailit dan seterusnya (Pasal 38 ayat (4) UUK.

4. Kreditur preferen khusus, sebagaimana terdapat di dalam Pasal 1139 KUHPer, dan Kreditur preferen umum, sebagaimana terdapat di dalam Pasal 1149 KUHPer; dan

5. Kreditur konkuren. Kreditur golongan ini adalah semua kreditur yang tidak termasuk Kreditur separatis dan tidak termasuk Kreditur preferan khusus maupun umum (Pasal 1131 jo Pasal 1132 KUHPer)

Dari lima golongan kreditur yang telah disebutkan diatas, berdasarkan Pasal 1134 ayat 2 jo.Pasal 1137 KUHPer dan Pasal 21 UU KUPerdt, kreditur piutang pajak mempunyai kedudukan di atas kreditur separatis. Sehingga posisi upah buruh berada dibawah biaya kepailitan dan fee kurator, yang berartiburuh harus lebih sabar dna berada dibelakang setelah harta boedel pailit dipakai untuk membayar pajak, kreditur pemegang jaminan kebendaan (Kreditur separatis), biaya kepailitan dan fee Kurator. Sehingga dengan posisi seperti ini, seringkali harta boedel pailit tidak cukup untuk membayar hak atau upah buruh.

Disinilah letak permasalahannya ketika suatu perusahaan mengalami pailit dan Kurator bertugas melakukan pemberesan harta pailit lebih menekankan pembagian boedel pailit setelah pembayaran pajak kepada kreditur separatis, biaya kepailitan dan fee untuk dirinya sendiri. Sehingga jika harta boedel pailit dalam jumlah yang terbatas seringkali hak-hak buruh tidak bisa diakomodir oleh si Kurator itu sendiri. Dalam kondisi seperti ini, Kurator seringkali mengenyampingkan hak-hak/utang gaji pekerja/buruh tersebut dikarenakan Kurator hanya bertindak menurut aturan dalam UUK tanpa memperhatikan aturan yang ada pada UU Ketenagakerjaan. Padahal posisi Kurator tesebut sebenarnya hanya sementara untuk menggatikan posisi Perusahan karena dalam keadaan pailit. Artinya Kurator juga harus bertindak sebagai Perusahaan yang wajib melindungi dan mengakomodir hak-hak Pekerja/buruh seperti yang diamanatkan UU Ketenagakerjaan. Permasalahan seperti ini seringkali menimpa buruh-buruh yang notabene hanya mengandalkan hidupnya dari upah yang diterimanya dari pekerjaan tersebut. Sehingga hal ini harus menjadi perhatian Pemerintah bagaimana caranya menyikapi perlindungan hak-hak buruh pasca putusan pailit dan memastikan kepentingan dan hakhak pekerja/buruh tetap terlindungi.

\section{PENUTUP}

\section{A. Kesimpulan}

1. Hak-Hak Normatif Pekerja Pada Perusahaan Yang Pailit menurut pasal 156 UU No, 13 tahun 2003 tentang ketenagakerjaan adalah uang pesangon sebesar 2 (dua) kali ketentuan Pasal 156 ayat (2), uang penghargaan masa kerja sebesar 1 (satu) kali ketentuan Pasal 156 ayat (3) dan uang penggantian hak sesuai ketentuan Pasal 156 ayat (4)" karena para pekerja merupakan kreditur Preferen dan menurut Undang-Undang Nomor 37 Tahun 2004, Hak Para Pekerja pada perusahaan tersebut menjadi Kreditur Prioritas setelah pemenuhan hak-hak kreditur separatis.

2. Kewenangan Kurator terhadap Hak Normatif Pekerja Pada Perusahaan Pailit adalah untuk menyelesaikan seluruh kepengurusan dan pemberesan harta dan hutang Debitur, termasuk Hak-Hak Normatif pekerja sebagimana yang telah diatur dalam Undang-Undang No. 13 tahun 2003 dan Undang-Undang No. 37 tahun 2004 tentang Kepailitan dan Penundaan kewajiaban Pembayaran Hutang, bahwa Hak-Hak Normatif Pekerja termasuk Kreditutr Preferen atau Kreditur yang di Prioritaskan. 
B. Saran

1. Untuk menjamin pemenuhan hak-hak normatif pekerja yang di PHK pada Perusahaan Pailiuy diperlukan perlindungan hak dan masa depan pekerja seperti melalui Suatu lembaga penjaminan/sejenis asuransi yang menjamin kepastian hak-hak dari pekerja tersebut akan dibayar jika perusahaan tempatnya bekerja dinyatakan pailit. sehingga pemenuhan hak-hak normatif pekerja dalam perusahaan tidak perlu dipersengketakan dipengadilan.

2. Kiranya Hak-Hak Normatif Pekerja yang di PHK pada Perusahaan yang sudah dinyatakan Paillit, patut didahulukan atau Kreditur Proiritas atau KredituirPreferen.

\section{DAFTAR PUSAKA}

Adrian Sutedi, Hukum Perburuhan, Sinar Grafika, Jakarta, 2009.

Ahmad Yani \& Gunawan Widjaja, Seri Hukum Bisnis Kepailitan, Pt Raja Grafindo Persada,Jakarta, 2002.

Asri Wijayanti, Hukum Ketenagakerjaan Pasca Reformasi, Sinar Grafika, Jakarta, 2013.

C.S.T Kansil \& Charistine Kansil, I Hukum Perusahaan Indonesia (Aspek Hukum Dalam Ekonomi), PT. Praddnya Paramita, Jakarta, 2001,

Gunawan Widjaja\& Ahmad Yani, Hukum Arbitrase, Pt Raja Grafindo Persada,Jakarta, 2003.

H. Tafrizal Hasan Gaweng, Panduan Singkat Praktek Kurator, THG, Yustisian, 2005,

H.Zaeni Asyhadie, \& Budi Sutrisno, Hukum Perusahaan \& Kepailitan, Penerbit Erlangga,Mataram, 2012

Imam Soepomo, Pengantar Hukum Perburuhan, Djambatan, Jakarta, 2003.

Jono, Hukum Kepailitan, Sinar Grafika, Jakarta, 2013.

Kartini Muljadi, Kreditor Preferens dan Kreditor Separatis Dalam Kepailitan, "Prosiding rangkaian lokakarya terbatas masalah-masalah kepailitan dan wawasan hukum bisnis lainnya , Jakarta, 2004.

Lalu Husni, Pengatar Hukum Ketenagakerjaan Indonesia, Edisi Revisi, PT . Raja Grafindo Persada, Jakarta, 2009.

M.Yahya Harahap,S.H. , Hukum Perseron Terbatas, Sinar Grafika, Jakarta, 2013.

S. Sastrawidjaja, Hukum Kepailitan dan Penundaan Kewajiban Pembayaran Utang, Jakarta, 2010.

Soerjono Soekanto dan Sri Mamudji, Penelitian Hukum Normatif, PT. Raja Grafindo Persada, Jakarta, 2001

Zainal Asikin, Hukum Kepailitan Dan Penundaan Pembayaran Di Indonesia, Pt Raja Grafindo Persada, Jakarta, 2001.

Undang-Undang No. 13 tahun 2003 tentang Ketenagakerjaan

Undang-Undang No. 37 tahun 2004 tentang Kepailitan dan Kewajiban Penundaan Pembayaran Hutang 